\title{
O MUMA EM ASSIS/ITÁLIA E A HISTÓRIA DOS FRADES CAPUCHINHOS DA ÚMBRIA NA AMAZÔNIA.*
}

The MUMA in Assis/Italy and the history of the Capuchin Friars of Úmbria in the Amazon.

Janaina Cardoso de Mello**

Resumo: O artigo analisa os usos sociais de cidades italianas com ruínas urbanas buscando identificar a relação entre museu e identidade na região da Úmbria; compreender o intercâmbio cultural entre Itália e Brasil presente na museografia do MUMA - Museu Missionário Índios em Assis (Itália) e estudar a história das missões dos Frades Capuchinhos italianos da Úmbria na Amazônia. As visitas técnicas in loco foram realizadas em 2011.

Palavras-chave: Museu Missionário; Itália; Amazônia.

Abstract: The article analyzes the social uses of Italian cities with urban ruins seeking to identify the relationship between Museum and identity in the region of Umbria; understand the cultural exchange between Italy and Brazil present in museography of MUMA-Missionary Museum Indians in Assisi (Italy) and study the history of the missions of Capuchin Friars Umbrian Italian in the Amazon. On-site technical visits were carried out in 2011.

Keywords: Missionary Museum; Italy; Amazon.

\section{REMEMORANDO}

O diário de campo que começava a ser escrito reportava-se à pesquisa sobre "Usos sociais de ruínas urbanas como patrimônio cultural da Arqueologia Histórica", integrante dos trabalhos de docência, pesquisa e extensão interdisciplinar junto ao Programa de PósGraduação em Arqueologia (PROARQ) da Universidade Federal de Sergipe (UFS), desenvolvido entre 2011 e 2013. A parte inicial do projeto compreendia a visita técnica à três cidades italianas: Perúgia, Assis e Roma, culminando com a apresentação de uma comunicação científica no XXXIII Convegno Internazionale di Americanistica promovido pelo Centro Studi Americanistici "Circolo Amerindiano" onlus, em Perúgia.

\footnotetext{
* Esse trabalho faz um agradecimento especial ao bibliotecário Samuel Silva, da Biblioteca Mario Ypiranga Monteiro, localizada no Centro Cultural dos Povos da Amazônia, situada Av. Silves, no 2.222, Distrito I Manaus/AM, pelo gentil acesso ao livro de Mario Tosti em sua versão digital promovido pelo Governo do Estado do Amazonas, Secretaria de Estado de Cultura e Gerência de Acervos Digitais.

** Doutora em História Social pela Universidade Federal do Rio de Janeiro (PPGHIS-UFRJ); Pós-Doutoranda em Estudos Culturais (PACC-UFRJ); Professora Adjunta do Departamento de História, do Mestrado Profissional em História (ProfHistória) da Universidade Federal de Sergipe (UFS) e do Mestrado em História da Universidade Federal de Alagoas (PPGH-UFAL). Contato: janainamello.ufs@gmail.com
} 
Estávamos em maio de 2011, em um dia primaveril daqueles em que chuva e sol brincavam de ciranda e olhar para o céu à cada momento trazia novas surpresas e a certeza de que tanto a sombrinha quanto os óculos de sol seriam necessários naquela jornada.

A partida acontecia da região da Úmbria, na Itália, na estação ferroviária de Perúgia com destino à estação ferroviária Santa Maria degli Angeli em Assis. Um percurso rápido, de carro via SS75 perfazendo 24 minutos e de trem/comboio um pouco mais de tempo em 29 minutos (figura 1). Escolhemos a segunda opção.

Figura 1: Rota Perúgia - Assis (Itália)

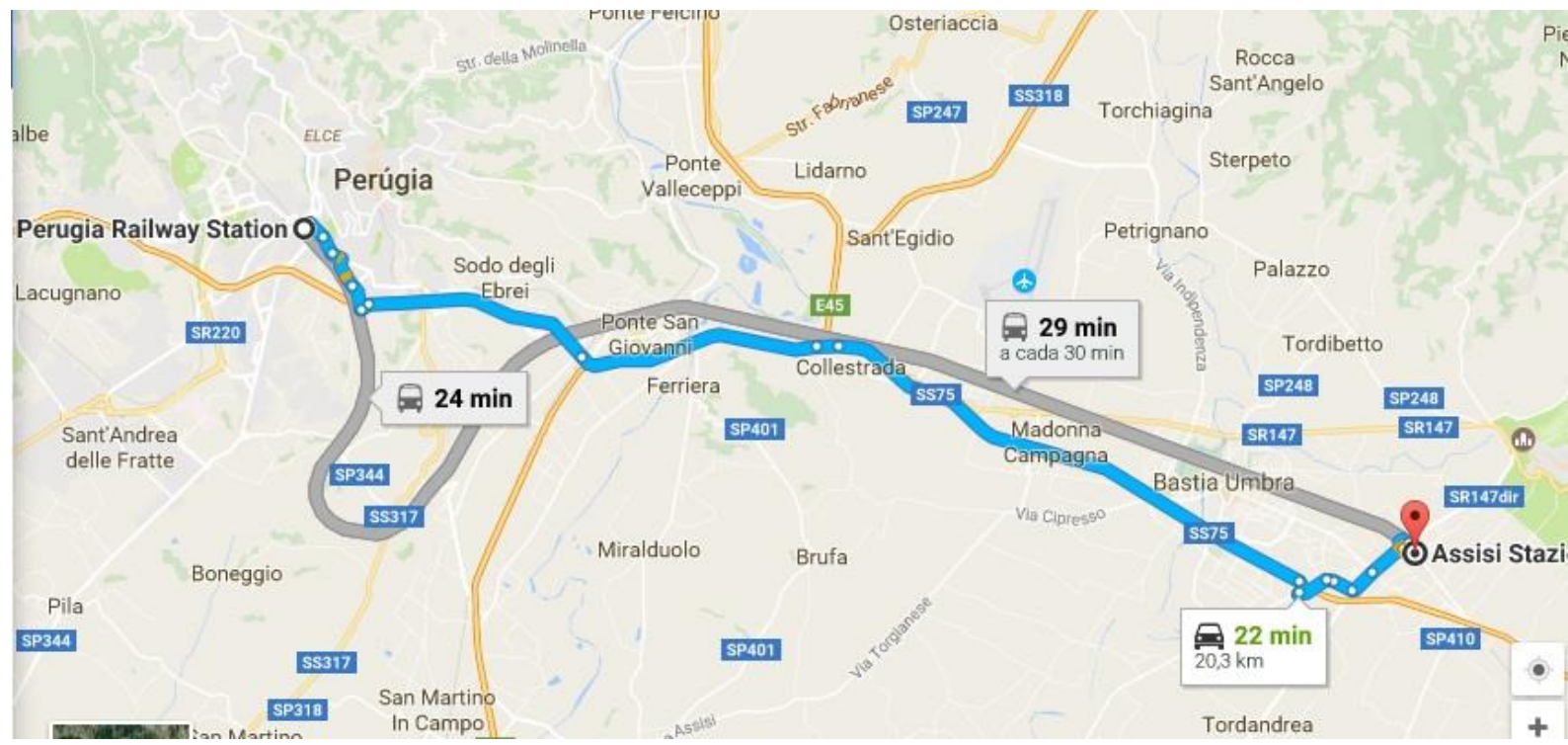

Fonte: Google Maps. Disponível em:

https://www.google.com.br/maps/dir/Perugia+Railway+Station,+Piazza+Vittorio+Veneto,+Perúgia,+Itália/Assis i+Stazione,+Santa+Maria+degli+Angeli, Acesso em: 13/04/2017.

A região da Úmbria é uma área da Itália central fronteiriça com a Toscana, possuindo $8456 \mathrm{~km}^{2}$ e 834 mil habitantes, cuja capital é Perúgia (figuras 3 e 4). Localidade com forte ancestralidade etrusca que pode ser encontrada principalmente no acervo do claustro e na tumba da família Cai Catu (séculos III a I a.c.) de um dos principais museus de Perúgia: o Museo Archeologico dell'Umbria (figura 2). 
Figuras 2, 3 e 4: Urnas e sarcófagos com inscrições etruscas e romanas no Museo Archeologico dell'Umbria; viela de Perúgia; Praça com fontana no centro de Perúgia.

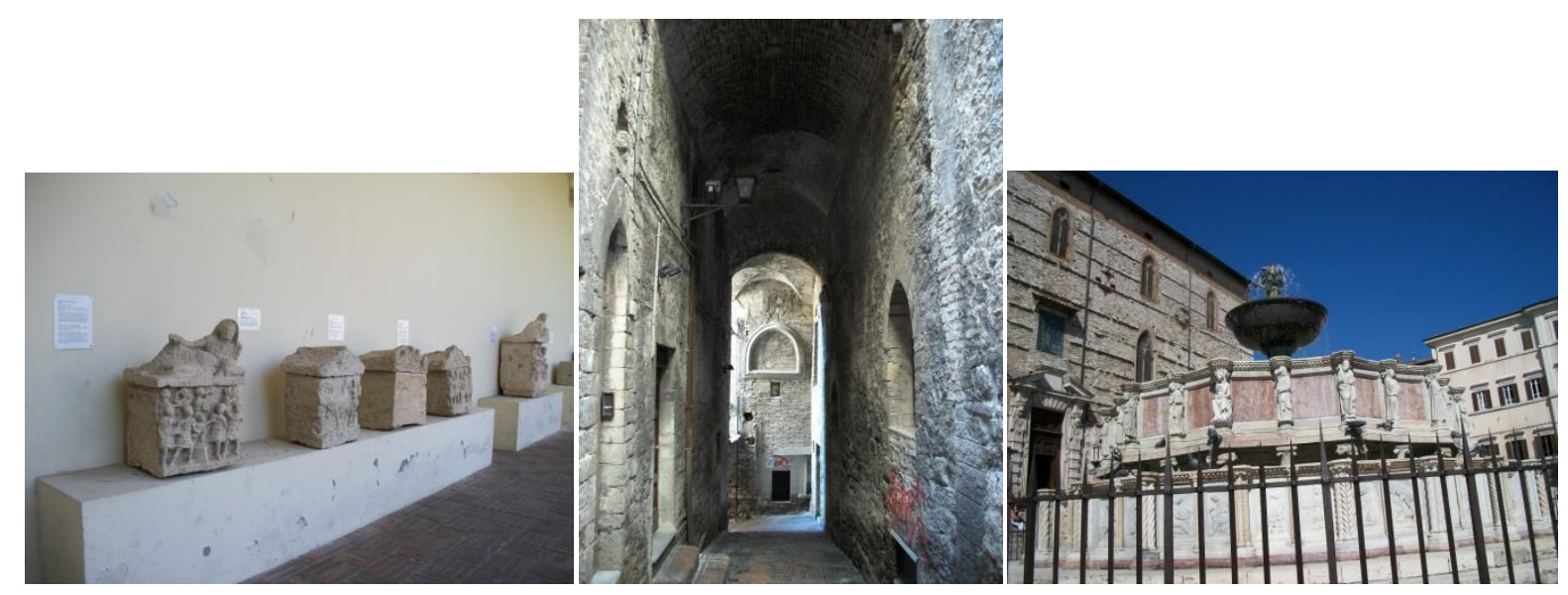

Fonte: Fotografia JCM, maio de 2011.

Entre 295 a.C e a metade do século XIII esse território foi palco de inúmeras contendas como a batalha de Santino, a Segunda Guerra Púnica, a batalha do lago Trasimeno, a guerra civil entre Marco Antonio e Otávio e as lutas entre ostragodos e bizantinos. Mas o grande papel de destaque para a Igreja Católica advém da Úmbria ser o abrigo do lugar de nascimento de Francisco de Assis (Francesco Bernadone), fundador da Ordem dos Franciscanos em 1208, e proclamado Santo em 1228 pelo Papa Gregório IX. ${ }^{1}$

A chegada à Assis é acompanhada do encantamento de presenciar uma poderosa arquitetura medieval incrustrada no Monte Subasio à 424 metros de altitude, oferecendo muradas protetoras que pareciam reluzir no encontro do sol com suas pedras polidas.

El paseo por sus calles plagadas de historia y de historias se hace inolvidable, y el amplio patrimonio, en especial las Basílicas franciscanas, la han hecho merecedora de pertenecer a la lista de patrimonio mundial de la UNESCO. ${ }^{2}$

Assis foi evangelizada por Rufino no século III, que também foi o primeiro Bispo local e que terminou sua vida como um mártir. Também é a cidade de Santa Clara (Chiara d'Offreducci), fundadora da Ordem das Clarissas. Dentre as imponentes edificações que as muralhas de Assis comportam estão: as duas fortalezas Rocca Maggiore e Rocca Minore, a Igreja de Santa Clara, a Capela de Santa Maria dos Anjos, a Catedral de São Rufino, a Igreja

\footnotetext{
${ }^{1}$ TROIANO, Constantino; POMPEI, Alfonso. Guia Ilustrada de Assis. Trad. Frei José Augusto Marques. Assis: Casa Editora Franciscana dos Frades Menores Conventuais; Umbriagraf-Terni, s/d.

2 "O passeio por suas ruas atormentadas por histórias e de histórias que se fazem inesquecíveis, e o amplo patrimônio, em especial as Basílicas franciscanas, as quais tiveram o direito de pertencer à lista de patrimônio mundial da UNESCO" Tradução livre de: Guia Turístico Asis, disponível em: http://www.europamundo.com/guiaspdf/Asis.pdf, p.207.
}

LCANOA DO TEMPO - O Muma em Assis/Itália e a história dos frades Capuchinhos da Úmbria na 
de São Pedro, a Igreja de Santa Maria Maggiore, o Convento de São Damiano, a Basílica de São Francisco de Assis e o Museu Missionário Índios dos Frades Capuchinhos da Úmbria na Amazônia ${ }^{3}$ (figura 5). Sendo, portanto, este último monumento, o objeto central de investigação histórica, etnográfica e museal nesse artigo.

Provenientes de um dos ramos da Ordem Franciscana fundada por Francisco de Assis no século XIII, os frades Capuchinhos chegaram ao Brasil em 1612, na Capitania do Maranhão. Após a criação da Diocese de Manaus os Capuchinhos lombardos, que já residiam na Amazônia desde 1606, assumiram duas prefeituras apotólicas: Rio Negro e Solimões. Em 1909 a recémcriada Prefeitura Apostólica de Alto Solimões foi assumida pelos Capuchinhos de Assis. ${ }^{4}$

A preocupação com a catequese dos índios no Brasil era algo que remontava à primeira metade do século XIX com o Decreto 426, de 24 de julho de 1845, contendo o "Regulamento acerca das missões de catequese e civilização dos índios". 5

Apesar de todo o esforço de regulamentação no último quartel oitocentista a Mensagem do Governador Eduardo Gonçalves Ribeiro, lida em 10 de julho de 1894 no Congresso do Estado do Amazonas, ainda chamava a atenção para a "necessária pacificação e civilização" dos índios Jauaperys, na margem do rio Solimões que ali se estabeleceram desde 1845 promovendo "correrias e morticínios" na Vila do Moura e vizinhanças. Segundo as palavras do presidente provincial, somente a restituição do sossego e da tranquilidade entre as povações incrementaria o comércio e o progresso da região. ${ }^{6}$

Sob esse aspecto, os clamores por mais auxílio e infraestrutura para incorporar os índios à sociedade amazonense sem derramento de sangue encontra sua resposta nas várias ordens religiosas estrangeiras (jesuítas portugueses e espanhóis, capuchinhos franciscanos italianos) que acorrem para uma região marcada pelo ciclo da borracha no início do século XX, migrações de nordestinos para os trabalhos nos seringais, imigrações de judeus comerciantes e inúmeros conflitos territoriais em uma área de abertura da navegação comercial nos rios da grande floresta.

\footnotetext{
${ }^{3}$ Idem, ibidem.

${ }^{4}$ HÜTTNER, Édison. A Igreja Católica e os povos indígenas do Brasil: os Ticuna da Amazônia. Porto Alegre: PUCRS, 2007, p.69.

${ }^{5}$ DECRETO no 426, de 24 de Julho de 1845. Disponível em: http://www2.camara.leg.br/legin/fed/decret/18241899/decreto-426-24-julho-1845-560529-publicacaooriginal-83578-pe.html, Acesso em: 16/04/2017.

${ }^{6}$ MENSAGEM do Sr. Governador Eduardo Gonçalves Ribeiro. Manaus: Imprensa Oficial do Estado do Amazonas, 1894, p.23-24. Disponível em: http://brazil.crl.edu/bsd/bsd/u1629/000022.html, Acesso em: 13/04/2017.
} 
Figura 5: Fachada do MUMA - Museo Missionario Indios em Assis (Itália)

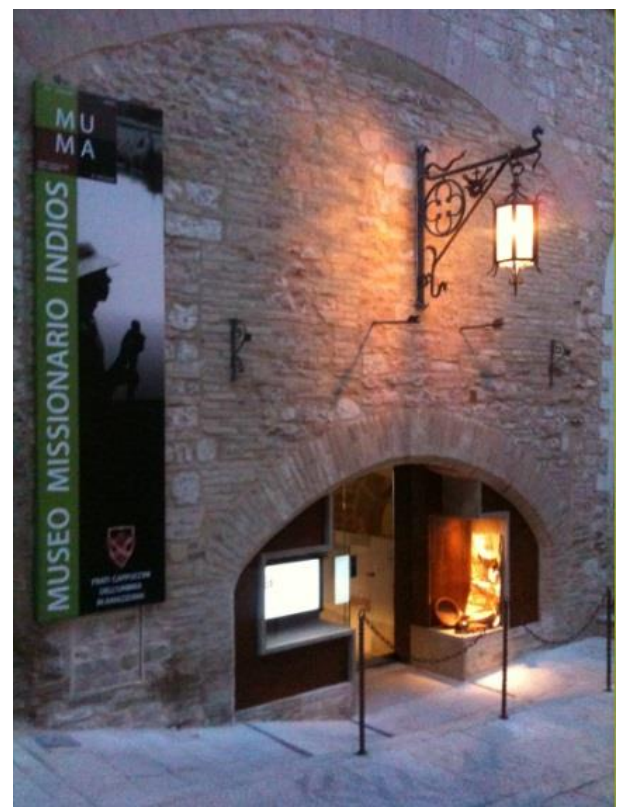

Fonte: http://www.mumamuseo.it, Acesso em: 13/04/2017.

A escolha específica por esse museu foi orientada por três motivações: primeiro em razão do museu encontrar-se como foco de uso social de uma cidade-monumento de ruínas arqueológicas; segundo, pela inserção de pesquisadores e bolsistas do projeto (PIBIC/CNPq e FAPITEC-SE) vindos do Departamento de Museologia da UFS e terceiro, devido ao fato de se tratar de um memorial do trabalho missionário de frades italianos na Amazônia brasileira.

O objetivo geral que norteou a pesquisa incidiu na análise dos usos sociais de cidades italianas com ruínas urbanas. Como objetivos específicos: identificar a relação entre museu e identidade na região da Úmbria; compreender o intercâmbio cultural entre Itália e Brasil na museografia do MUMA e estudar a história Frades Capuchinhos da Úmbria na Amazônia corporificada no MUMA - Museu Missionário Índios em Assis (Itália).

A metodologia adotada para a coleta de dados seguiu passos de uma pesquisa exploratória e explicativa, levantamento bibliográfico e mapeamento do território do objeto de estudo via uma etnografia de percurso in loco com entrevistas contextuais vinculadas ao padrão de análise das representações sociais e identitárias presentes na História Cultural.

EM NOME DO PAI, DOS “ÍNDIOS" E DO ESPÍRITO SANTO: OS CAPUCHINHOS ITALIANOS NA AMAZÔNIA.

LCANOA DO TEMPO - O Muma em Assis/Itália e a história dos frades Capuchinhos da Úmbria na Amazônia. 
A Amazônia na virada do século XX tornou-se uma região de grande pluralidade cultural dada a existência de várias nações indígenas como também pela grande afluência de imigrantes europeus para seu território interessados em fugir das guerras européias e fazer fortuna nas terras brasileiras.

Apesar da violência do contato e do esbúlio de terras indígenas, portugueses, espanhóis, japoneses, judeus-franceses e marroquinos e sírios libaneses deixaram sua contribuição para o desenvolvimento educacional, comercial, na área da saúde e da própria infraestrutura. Da contribuição italiana ressaltam-se:

[...] obras de arte realizadas como a dos pintores Domenico de Angelis e Giovani Capranesi, que pintaram o salão nobre do Teatro Amazonas, o teto do Salão do Teatro da Paz e da Igreja da Sé em Belém; o arquiteto bolonhês Antonio Landi, autor do projeto do Palácio Lauro Sodré, Palácio Antônio Lemos e outros edifícios em Belém; o dono do Hotel Cassina - Andrea Cassina; o comerciante Pusinelli, o sócio da firma Prussi, Pusinelli \& Cia., a maior firma exporetadora de Manaus no ano de 1897; o empresário G. Fradelizi, grande comerciante e exportador de cacau de Belém e Itacoatiara, nos anos 1910/1916. Outra grande contribuição italiana à cidade de Manaus e à Amazônia foi a da companhia de navegação La Ligure Brasiliana, presidida pelo deputado italiano Gustavo Gavotti, que inaugurou, em 1897, a linha Gênova-Manaus, com escalas em Marselha, Barcelona, Tânger (Marrocos), Lisboa, Madeira, Belém, Santarém e Óbidos. ${ }^{7}$

A administração religiosa católica das "almas da Amazônia" data de 1719, quando foi instituída a Diocese do Grão-Pará abrangendo os rios Amazonas e Solimões. A divisão em três Vicariatos-Gerais aconteceu posteriormente, em 1755, com sedes em Cametá, no rio Tocantins; em Santarém, no rio Amazonas, e na "Cidade da Barra" (atual Manaus) o Vicariato Amazonas, no rio Negro. Em 1892 foi fundada a Diocese do Amazonas, com sede em Manaus e tendo como primeiro Bispo Dom José Lourenço da Costa Aguiar. ${ }^{8}$

No concurso da catequese indígena na Amazônia, outros italianos haviam marcado presença antes dos frades da Úmbria na região Amazônica, assim, o trabalho missionário fora realizado por franciscanos de Milão à exemplo do Frei Jesualdo Macchetti que veio a falecer em $1902 .{ }^{9}$

\footnotetext{
${ }^{7}$ BENCHIMOL, Samuel. Amazônia. Formação Social e Cultural. Manaus: Ed. Valer, 2009, p.450.

${ }^{8}$ TOSTI, Mario. A igreja sobre o rio. A missão dos Capuchinhos da Úmbria no Amazonas. Roma/Manaus: Secretaria de Cultura de Estado, 2012, p.12.

${ }^{9}$ RODRIGUES, Carrie Carolinne Evans Ferreira. O Acervo Pictórico da Igreja de São Sebastião em Manaus. Dissertação de Mestrado em Letras e Artes. Manaus: Programa de Pós-Graduação em Letras e Artes/Universidade Estadual do Amazonas, 2016, p.25.
} 
Figura 6: Frades Capuchinhos de Assis, Úmbria.

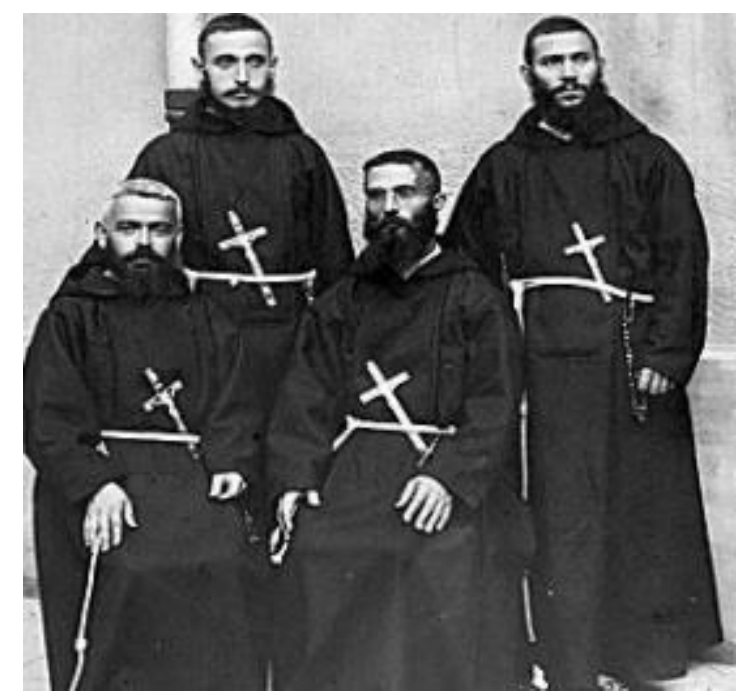

Fonte: Arquivo particular da Igreja de São Sebastião, 1909 apud RODRIGUES, Carrie Carolinne Evans Ferreira. O Acervo Pictórico da Igreja de São Sebastião em Manaus. Dissertação de Mestrado em Letras e Artes. Manaus: Programa de Pós-Graduação em Letras e Artes/Universidade Estadual do Amazonas, 2016, p.26.

Selecionados por seus religiosos superiores da Úmbria, um quarteto de franciscanos (figura 6) composto por Pe. Frei Domenico de Gualdo Tadino, Pe. Frei Hermenegildo de Foligno, Pe. Frei Agatângelo da Spoleto e Frei Martino de Ceglie estabeleceu-se em Manaus a partir de 26 de julho de 1909, substituindo frades milaneses e lombardos. ${ }^{10}$

Dizia a Cronaca della Missione di Rio Negro nel Brasile: “A Província Seráfica capuchinha, qual herdeira legítima do espírito de S. Francisco teve sempre especial atenção às santas missões e sempre nutriu no próprio seio bons missionários". ${ }^{11}$

Do início das atividades religiosas dos Capuchinhos da Úmbria até a década de 1920, o trabalho compreendia o contato com os povos indígenas e a administração de sacramentos, principalmente no que dizia respeito à "regularização da situação conjugal para uma plena adesão à fé católica". Era uma fase marcada pelo etnocentrismo intelectual que via o nãoeuropeu como um bárbaro à civilizar pelos "ensinamentos superiores", destruindo aquilo que era considerado errado e imoral, delimitando assim a "conquista do outro". ${ }^{12}$

\footnotetext{
${ }^{10}$ Idem, ibidem, p.26.

11 APCA, 101, Missioni - Storia, 3, Cronaca (1906-1911), Cronaca della Missione di Rio Negro nel Brasile (America) proposta dalla Sacra Congregazione di Propaganda Fide e dal rev.mo p. generale Pacifico Seggiano [...] alla nostra Provincia Serafica il 5 marzo 1909 ed accettata con lettera del 10, marzo, 1909 dal M. R. P. Giulio da Perugia ministro provinciale e suo Definitorio Provinciale (de agora em diante Cronaca della Missione).

12 TOSTI, Mario. Op. cit., p. 18.

LCANOA Do TEMPO - O Muma em Assis/Itália e a história dos frades Capuchinhos da Úmbria na Amazônia.
} 
Os primeiros momentos dos frades Capuchinhos da Úmbria na Amazônia não foram dos melhores e suas cartas à Itália retratavam a desilusão dos missionários na evangelização de uma "terra hostil", com a alimentação "de difícil digestão", um clima com altas temperaturas, “mosquitos ávidos", população quase desnuda, mal estar e mortes por "febre amarela". ${ }^{13}$

A cronologia da ação missionária entre 1910 e 1946, além dos trabalhos religiosos remonta aos cuidados educacionais e da saúde das populaçãoes locais. Assim,

Os missionários capuchinhos italianos logo iniciaram seu apostolado atendendo, além das necessidades espirituais, a carência de educação e da saúde. No primeiro mandato do Fr. Evangelista Cefalônia (1910-1938), foram construídos a sede da Prefeitura Apostólica e o primeiro educandário em São Paulo de Olivença. O segundo prefeito da missão a tomar posse em 1938 foi mons. Tomas de Marcelano. Em São Paulo de Olivença, construiu uma nova escola, assim como em Benjamin Constant em 1940, cujo serviço educacional ficou a cargo da Congregação das Irmãs Franciscanas. Fr. Tomas faleceu em 1945 num naufrágio no rio Solimões perto de Santo Antônio do Içá. Em seu lugar, assumiu mons. Wenceslau de Spoleto em 1946. Este continuou o apostolado na edificação de escolas. Em Amaturá fundou o Orfanato e o Santuário de Amaturá. ${ }^{14}$

O trabalho missionário da catequese junto aos índios Ticuna somente teve seu início em 1926, com a chegada de Frei Fidélis de Alviano em Belém do Solimões. Sua importância naquela ação ficou registrada na primeira Gramática Ticuna, lançada em 1949, após ter aprendido a escrita e fala daquela língua indígena. ${ }^{15}$ Nesse empreendimento havia um maior “[...] esforço para compreender as estruturas sociais das populações indígenas". ${ }^{16}$

Figuras 7 e 8: Trabalho missionário dos Capuchinhos da Úmbria nas aldeias indígenas
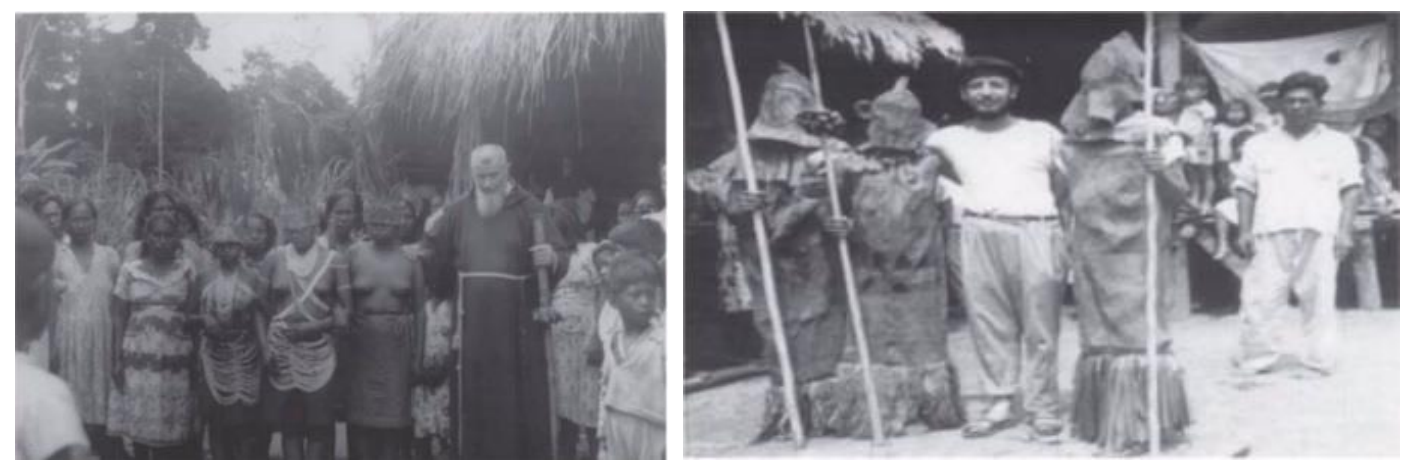

Fonte: TOSTI, Mario. A igreja sobre o rio. A missão dos Capuchinhos da Úmbria no Amazonas. Roma/Manaus: Secretaria de Cultura de Estado, 2012, pp.97;100.

Em 1934, Frei Fidélis foi oficialmente encarregado da evangelização e do relacionamento com as comunidades indígenas (figuras 7 e 8), iniciando neste mesmo ano o

\footnotetext{
${ }^{13}$ Idem, ibidem, p.34-35.

${ }^{14}$ HÜTTNER, Édison. Op. cit., p.70.

${ }^{15}$ Idem, ibidem, p.70.

${ }^{16}$ TOSTI, Mario. Op. cit., p. 18.
} 
primeiro recenseamento dos Ticunas naquelas terras e contabilizando um total de 5.000 índios. ${ }^{17}$ Sua ação missionária compreendia a escolha de uma cabana onde reunia os residentes e, segundo suas palavras:

[...] ali permanecia por 60 dias a instruir e a administrar os santos sacramentos. À instrução vinham crianças e adolescentes durante o dia e à noite vinham todos até formarem uma pequena multidão. Para atraí-los valiam muito o harmônio e o gramofone, assim como outros divertimentos e premiações que fazia todo domingo com pequenos objetos e roupas àqueles que mais assídua e diligentemente esforçavam-se para aprender. Depois de 60 dias fazia a escolha daqueles que podiam ser admitidos à primeira comunhão. ${ }^{18}$

No plano lingüístico "os índios Ticuna autodenominavam-se a nação magũta que significa 'povo pescado com vara' por Yo’ $i$, herói mitológico do povo Ticuna". ${ }^{19}$ Ressalta-se ainda que historicamente:

Os Ticuna, em sua origem, sempre foram índios de terra firme, ocupando um extenso território no alto dos igarapés que deságuam no Rio Solimões, mas com o passar dos anos foram se deslocando cada vez mais, e a partir do final do século XVIII foram em direção ao grande Rio Solimões. Esse processo teve início com o desaparecimento gradativo de seus inimigos rivais, os Omágua (também chamados de Cambeba) tribo guerreira que dominava as margens do Rio Solimões. Os Ticuna, que fugiam com as agressões desse povo, refugiavamse no alto dos igarapés e afluentes da margem esquerda do Rio Solimões, faziam o mesmo com a chegada dos espanhóis, em especial Francisco Orellana e suas expedições. ${ }^{20}$

No relatório de 1927, os frades Capuchinhos umbros fazem uma fervorosa denúncia contra os "patrões" que escravizam índios e seringueiros, a incompetência das autoridades locais em resolver o problema, muitas vezes cúmplices da exploração, facilitando assim que os ditos patrões tornem-se “[...] verdadeiros senhores feudais, déspotas da vida e da alma do infeliz seringueiro". ${ }^{21}$

Nem a morte de Frei Fidélis, em 1953, interrompeu o trabalho missionário dos Capuchinhos junto aos índios Ticunas, pois outros missionários vindos da Úmbria prosseguiram com as ações à exemplo do Frade Geremias de Intermesoli, responsável pela Pastoral Indígena entre 1962 e 1964. Ainda o Frade Arsénio Sampalmieri, também foi uma das

\footnotetext{
${ }^{17}$ Idem, ibidem, p.239-240.

${ }^{18}$ Idem, p.240.

${ }^{19}$ CARVALHO, Ana Letícia Ferreira de. Estudo Sociolinguístico em situação de contato em contexto escolar: os alunos indígenas Ticuna na Universidade do Estado do Amazonas-UEA. Anais do VI SAPPIL - Estudos de Linguagem, UFF, no 1, 2015, p. 41.

${ }^{20}$ Idem, ibidem, p.41.

${ }^{21}$ TOSTI, Mario. Op. cit., p. 220
}

LCANOA DO TEMPO - o Muma em Assis/Itália e a história dos frades Capuchinhos da Úmbria na Amazônia. 
lideranças junto à Pastoral dos índios Ticunas a partir da promoção da capela de Belém do Solimões em Igreja Paroquial. ${ }^{22}$

\begin{abstract}
Além de prestar o serviço espiritual, ministrando os sacramentos, Arsênio administrava uma pequena indústria e servia como intermediário para vender seus produtos no mercado das cidades de Benjamin Constant, Tabatinga e Letícia, na Colômbia. No que diz respeito à demarcação de terras para os Ticuna na época, Arsênio apresenta seus argumentos para a Fundação Nacional do Índio. ${ }^{23}$
\end{abstract}

Com o índios Ticunas os Capuchinhos italianos aprenderam o conhecimento da hidrografia amazônica como meio de transporte, fonte de água doce, viveiro de plantas, peixes e animais; o aproveitamento das várzeas dos rios; a convivência e adaptação ao regime de enchentes e vazões fluviais no uso de terras e águas; o uso da floresta e o conhecimento sobre a tipologia de madeiras destas; a construção de meios de transporte fluviais (canoas, chalanas, jangadas, balsas); as práticas agrícolas dos roçados de mandioca e seu preparo; as técnicas de desmatamento da floresta por broca, derrubada, queima e coivara; a caça e identificação dos animais silvestres; a pesca e identificação das várias espécies de pescados; a apanha de bichos de casco; a construção de casas de paxiúba e palha de buçu, de pau-a-pique, palafitas, malocas, flutuantes; o artesanato em cuias, paneiros, jamaxis, cestos, tipitis, redes e cerâmicas, amuletos, plumaria, tecelagem; a culinária e preparo de peixes; a descoberta de frutos silvestres; a revelação e preparação de raízes e tubérculos de grande valor alimentício; a divulgação de bálsamos e resinas voláteis; o acesso à fibras como piaçava, tucum, malva, jauari, buçu, miriti, uacima; plantas e ervas medicinais como a andiroba, capim-santo, cidreira, erva-de-bicho, jambu, jurubeba, malva, mastruz, quebra-pedra; várias especiarias; alucinógenos; lendas, mitos e crenças do imaginário indígena. ${ }^{24}$

É essa história, dos primeiros frades Capuchinhos na Amazônia e seus continuadores ao longo de cem anos, as dificuldades, as contradições e ambiguidades entre o medo e a adaptação, a conquista da civilização e o olhar da solidariedade que liberta, o trabalho missionário humanista e o etnocentrismo de seu tempo, a cultura material indígena do exotismo à ideia de ciência, a ocupação de terras e rios à montagem de uma infraestrutura local que o próprio Estado brasileiro inicialmente foi incapaz de erguer naquelas áreas indígenas que o MUMA levará para sua museografia.

\footnotetext{
${ }^{22}$ HÜTTNER, Édison. Op. cit., pp.71-72.

${ }^{23}$ Idem, ibidem.

${ }^{24}$ BENCHIMOL, Samuel. Op. cit., p.26-29.
} 


\section{UM MUSEU-MUNDO DE UM PATRIMÔNIO EXTRA-TERRITORIAL ENTRE REPRESENTAÇÕES E APROPRIAÇÕES CULTURAIS NA MUSEOGRAFIA.}

O MUMA - Museu Mussionário Índios remonta ao ano de 1973 como herança do Museu dos Índios da Amazônia concebido pelo padre Luciano Matarazzi, constituído a partir das doações dos missionários que lhe traziam material indígena coletado nas viagens entre o Alto Solimões e Assis.

Uma exposição missionária realizada em Roma, no ano de 1925, para a celebração do Ano Jubilar, atendeu a solicitação do Papa Pio XI no envio de testemunhos da história e da vida nas missões, além de manifestações da fauna, flora, arquitetura, pintura, tradições, obras de evangelização, dentre outras. Os frades Capuchinhos da Úmbria, habitantes do Alto Solimões, enviaram testemunhos de mais de quinze anos de sua presença no Amazonas e produtos como: uma coleção de borboletas e de pássaros, peles de animais selvagens, e dentre eles a pele da serpente Sucuriiu com oito metros. ${ }^{25} \mathrm{O}$ processo de traslado, concepção, montagem e avaliação da exposição do acervo da Amazônia fora feito sob o crivo do Frei Hermenegildo, desse modo,

A mostra dos missionários umbros foi visitada inclusive pelo santo padre que admirou a beleza e a variedade das plantas e dos animais presentes naquele ângulo da terra, congratulou-se com Fr. Hermenegildo de Foligno, que havia acompanhado o material da exposição até Roma e a tinha organizado e exprimiu o desejo de numa futura nova mostra admirar também uma "coleção cinetífica dos vários insetos da Amazônia". ${ }^{26}$

Em 1949, buscando uma nova divulgação da cultura material e do artesanato indígena outra exposição em Roma terminou por fornecer mais subsídios para a fundação do Museu de Assis. $^{27}$

O acervo do antigo museu era composto por uma variedade tipológica e quantitativa de flores, frutos, peixes, insetos, répteis e utensílios diversos. As demandas do século XXI incidiram sobre o museu que passou por um processo de transformação significativa: de museu tradicional ao museu tecnológico.

Los museos son instituciones que han sido consideradas por muchas voces profesionales y por la opinión pública como instituciones en continuo proceso de cambio. Las razones que justifican esta afirmación podrían ser clasificadas en tres categorías: las derivadas de la evolución propria del museo y las

\footnotetext{
${ }^{25}$ TOSTI, Mario. Op. cit., p.216.

${ }^{26}$ Idem, ibidem.

${ }^{27}$ Idem, p. 19.
}

LCAnOA Do TEMPO - O Muma em Assis/Itália e a história dos frades Capuchinhos da Úmbria na 
funciones que lo definen, las generadas como consecuencia de las nuevas prestaciones que la sociedad demanda, y las resultantes de las exigencias que las administraciones, titulares y gestoras, requieren de esta institución cultural donde los conceptos de rentabilidad y sostenibilidad económica se han incorporado bajo unas nuevas premisas de gestión. ${ }^{28}$

Assim, foi realizado um conjunto de metodologias museográficas que envolveram: a documentação fotográfica e um inventário das peças, conformando a documentação museológica institucional; procedimentos de conservação preventiva junto aos materiais antropológicos (madeira, cerâmica, vime, fibras vegetais, etc.) em estado não tão danificados e de restauração dos animais empalhados que encontravam-se em condições de avançada deterioração.

O processo de conservação e/ou restauração em um museu envolve alguns critérios essenciais: 1. Assegurar-se das normativas da instituição e das prerrogativa nacionais e internacionais da área; 2. Verificar e descrever o estado de conservação e necessidades de restauração das coleções com um máximo de detalhamento para chegar à algumas conclusões (bom: não requer nenhuma intervenção; regular: requer uma intervenção mínima; mal: requer uma intervenção integral e urgente); 3. Planejar e executar os processos de conservação preventiva em áreas públicas e internas com as coleções (condições ambientais: mínimas e máximas, temperatura, umidade relativa; iluminação: fontes e medições; contaminação: sintomas observados e soluções adotadas de acordo com a contaminação - biológica, atmosférica, acústica); 4. Observar os critérios gerais do museu para manipulação, armazenagem e exposição das coleções. Em caso de restauração, há que se cuidar do planejamento antes, durante e depois, ou seja, quais objetos serão restaurados, quais os procedimentos, planejamento, documentação e conservação à posteriori. ${ }^{29}$

Após essa primeira fase, era necessário cuidar da reformulação da expografia do museu, por isso aqueles objetos mais bem conservados e significativos para a trajetória missionária dos

\footnotetext{
28 "Os museus são instituições que tem sido consideradas por muitas vozes profissionais e pela opinião pública como instituições em contínuo processo de mudança. As razões que justificam esta afirmação poderiam ser classificadas em três categorias: as derivadas da evolução própria do museu e as funções que o definem, as geradas como consequência dos novos benefícios que a sociedade demanda, e as resultantes das exigências que as administraç̃oes, proprietárias e gestoras, requerem desta instituição cultural onde os conceitos de rentabilidade e sustentabilidade econômica se têm incorporado sob novas premissas de gestão" Tradução livre de: GÓMEZ, Marina Chinchilla. La planificación y los museos. In: LACASTA, Ana Azor; PERAILE, Isabel Izquierdo (Coord.) Actas de las Primeras Jornadas de Formación Museológica. Museos y planificación: Estratégias de futuro. Espanha: Secretaría General Técnica Subdirección General de Publicaciones, Información y Documentación/Ministerio de Cultura, 2006, p.20.

${ }^{29}$ GAMO, Rubí Sanz. El Plan Museológico del Museo Arqueológico Nacional. In: LACASTA, Ana Azor; PERAILE, Isabel Izquierdo (Coord.) Op. cit., p.85.
} 
frades italianos na Amazônia foram acondicionados em novos expositores. Dois diadoramas ${ }^{30}$ foram elaborados para alocação dos animais empalhados, reconstituindo o ambiente natural da floresta pluvial da Amazônia enquanto um terceiro diadorama foi situado na sala destinada ao cotidiano dos índios Ticunas, com a representação de uma maloca. Ressalta-se que:

El museo contemporáneo se convierte en un elemento mediático, que apuesta por las escenografías interpretativas o por escenografiar las colecciones. Se seleccionan objetos en función de una idea, una interpretación y una reflexión, se elabora una estrategia de comunicación y se busca la experiencia y el espíritu del lugar que atraiga y envuelva al visitante. ${ }^{31}$

A expografia anterior da instituição possuía um ambiente cheio de informações que terminava poluindo visualmente a comunicação museológica sobre o acervo e o trabalho missionário dos frades capuchinhos italianos na Amazônia (figura 9). Quando se aprende o valor de uma "reserva técnica" (lugar no museu onde se pode guardar parte do acervo, catalogado e conservado, para que o mesmo possa integrar exposições de curta duração, itinerantes e revitalizar as alterações na exposição de longa duração após cinco anos de sua manutenção) qualquer ambiente expositivo ganha um ar mais clean.

Figuras 9 e 10: Expografia do Museu dos Índios da Amazônia concebido pelo padre Luciano Matarazzi em 1973

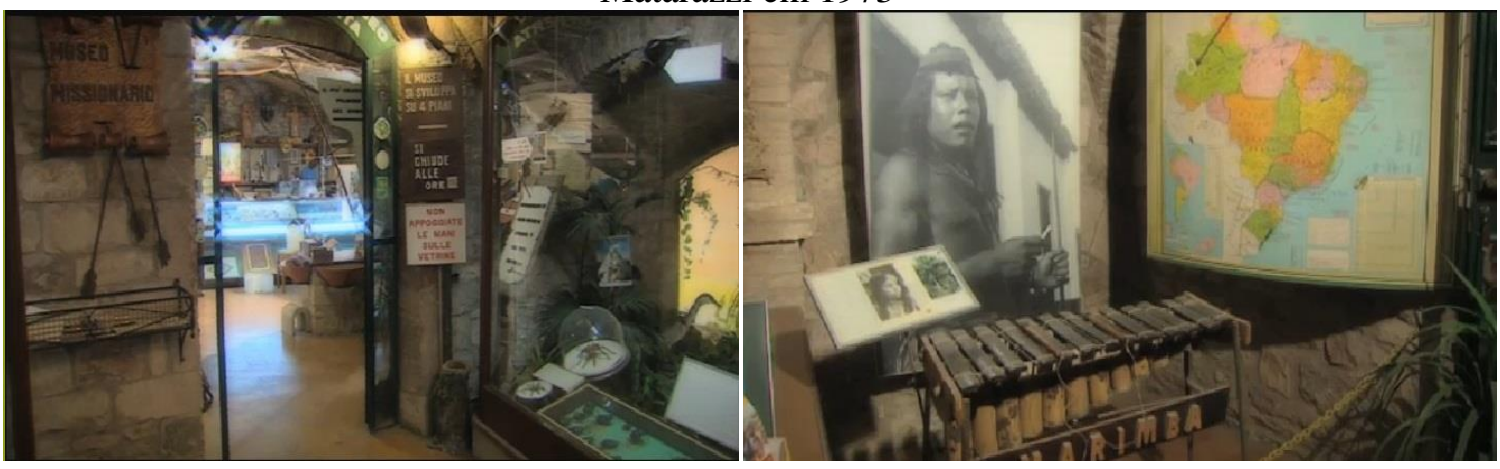

Fonte: http://www.mumamuseo.it, Acesso em: 13/04/2017.

Não havia recursos digitais e a iluminação muito clara terminava refletindo no vidro dos expositorers transformando-os em espelhos refratores, dificultando muitas vezes a visualização

\footnotetext{
${ }^{30}$ Diadorama é um modo de apresentação artística tridimensional, de maneira muito realista, de cenas da vida real para exposição com finalidades de instrução ou entretenimento.

31 "O museu contemporâneo se converte em um elemento mediático, que aposta pelas cenografias interpretativas ou por cenografar as coleções. Se selecionam objetos em função de uma ideia, uma interpretação e uma reflexão, se elabora uma estratégia de comunicação e se busca a experiência e o espírito do lugar que atraia e envolva o visitante" Tradução livre de: LLOVERA, Xavier. Una sociedad en transformación, nuevos retos museísticos: la apuesta por un Turismo Cultural. In: NASCIMENTO JÚNIOR, José do; CHAGAS, Mário de Souza (Orgs.) IBERMUSEUS 2 (2007: Salvador, BA): Reflexões e Comunicações. $2^{\text {a }}$ Edição. Brasília, DF: Instituto Brasileiro de Museus, 2010, p.23.
}

LCANOA DO TEMPO - O Muma em Assis/Itália e a história dos frades Capuchinhos da Úmbria na Amazônia. 
do acervo. Todavia, salienta-se o cuidado do museu com as informações corretas sobre a geografia brasileira e a iconografia dos índios Ticunas (figura 10).

Para a modernização, houve a digitalização dos expositores apresentando fotos em movimento e com sonoridade, cuidando-se da iluminação dos espaços em tons de meia luz conformando-se aos sons das florestas. $\mathrm{O}$ museu passou a utilizar ainda audioguias com idiomas em italiano, inglês e português.

Tabela 1: Particularização do Plano Museológico Multimídia do MUMA

\begin{tabular}{|l|l|}
\hline \multirow{2}{*}{ Projeto Sonoro } & $\begin{array}{l}\text { Dois níveis de som ambiente, distintos em cada sala, locução mixada que } \\
\text { acompanha o visitante conferindo à cada objeto do acervo sua } \\
\text { ambientação correta. O som da floresta foi gravado no Alto Solimões } \\
\text { entre 2006 e 2010. As músicas advém do festival de música indígena } \\
\text { realizado em Belém do Solimões, tradição da nação indígena Ticuna. }\end{array}$ \\
\hline Projeto Interativo & $\begin{array}{l}\text { Cada sala do museu permite ao visitante o contato direto com a realidade } \\
\text { ambiental e humana do Alto Solimões via personagens virtuais, mapas } \\
\text { animados, projeções que se revezam, intercalados com 25 vitrines nas } \\
\text { quais foram colocadas as peças mais bem conservadas herdadas do } \\
\text { primeiro museu Etnográfico aberto em 1973. }\end{array}$ \\
\hline Projeto Informacional & $\begin{array}{l}\text { Existem quatro colunas de aprofundamento temático, com 300 fotos } \\
\text { antigas e 20 filmes (alguns dos anos 1950) e dois computadores que } \\
\text { oferecem acesso ao acervo integral do museu. }\end{array}$ \\
\hline
\end{tabular}

Fonte: Elaboração própria a partir dos dados disponíveis em: http://www.mumamuseo.it, Acesso em: $13 / 04 / 2017$

Quando se transpõe o mundo do museu tradicional focado nos objetos para o museu multimídia, no qual a tecnologia e a experiência do visitante direcionam olhares, sensações e apreensões do conhecimento comunicado novos desafios são postos: 1. Perceber o poder de atratividade junto ao público mais jovem; 2. Propiciar um exercício interativo de evocação de memórias; 3. Ressignificar o tradicional em uma nova linguagem capaz de tornar viva a interdisciplinaridade dos conteúdos expositivos.

No caso do Museu Missionário Índios de Assis, retomando o diário de campo iniciado em maio de 2011, há a promoção da coexistência de distintos tempos na experiência do visitante, uma vez que antes de adentrar a instituição, são as muralhas medievais, sua cultura de Justas e cavaleiros, cores azuis e vermelhas distribuídas em estandartes pelas ruas italianas que envolvem um momento inicial de descobertas.

O museu age como um portal transportando o visitante para um Brasil amazônico, de cores, sons, aromas e imagens que mesclam a religiosidade missionária dos Capuchinhos às tradições dos índios Ticunas nas margens do rio Solimões. O barulho da chuva caindo, dos bichos da floresta, do canto indígena configuram-se em "saudade" para o brasileiro e em "curiosidade" para o estrangeiro. Reforçam-se as noções de hands-on, minds-on e hearts-on ao estimular-se o afetivo através da sensorialidade, mas que ao mesmo tempo não apresenta um 
"museu sem acervo", pois lá estão os utensílios em palha trançada, as cuias feitas de coco, as cerâmicas, ou seja, um rol de elementos materiais do cotidiano daquele povo ali representado (figura 11).

Figuras 11: Expositores com acervo materialo e recursos digitais interativos

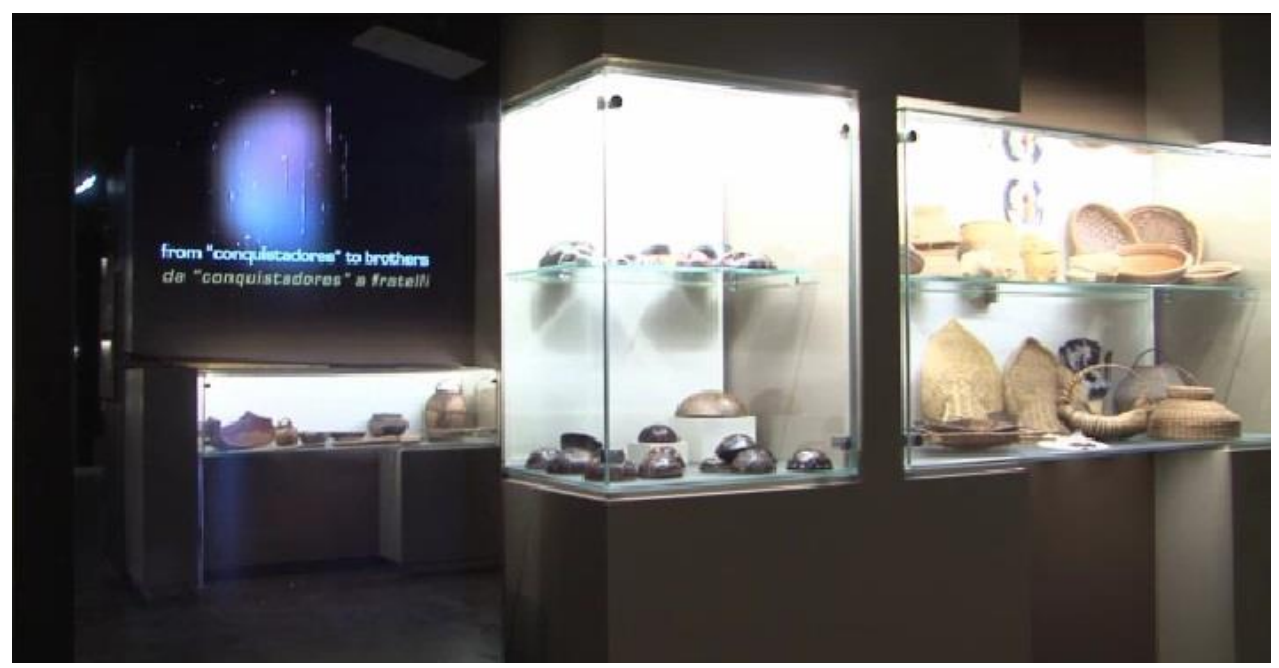

Fonte: http://www.mumamuseo.it, Acesso em: 13/04/2017.

Durante a etnografia de percurso concretizada em Assis e no MUMA, foram realizadas algumas entrevistas contextuais no formato de bate-papo, tomando-se nota das "paroles" de três pessoas relacionadas de alguma forma ao museu e à cidade. Parte-se do princípio de que:

a pesquisa etnográfica constituindo-se no exercício do olhar (ver) e do escutar (ouvir) impõe ao pesquisador ou a pesquisadora um deslocamento de sua própria cultura para se situar no interior do fenômeno por ele ou por ela observado através da sua participação efetiva nas formas de sociabilidade por meio das quais a realidade investigada se lhe apresenta. ${ }^{32}$

Com esse procedimento observou-se que narrativa histórica que serve de elo entre o passado e o presente introduz os quatro frades pioneiros no MUMA - Museu Missionário Índios em Assis e é absorvida por Sante Altizio ao afirmar que:

[...] são quatro homens que saem de Assis, seu recanto, para uma terra incógnita, onde irão desenvolver seu trabalho religioso em 1909. A missão dos Capuchinhos italianos de Úmbria é uma metáfora de um encontro tal qual o rio Negro com o rio Solimões. Águas distintas que se conjugam, duas culturas estranhas uma à outra que seguem paralelamente como os rios. ${ }^{33}$

\footnotetext{
32 ROCHA, Ana Luiza Carvalho da; ECKERT, Cornelia. Etnografia: saberes e práticas. Iluminuras, v. 9, n. 21, 2008 , p.2.

${ }^{33}$ Entrevista com o escritor e documentarista, nascido em Turim em 1966, formado pela Università degli Studi di Torino, realizada em maio de 2011.
} 
As telas touch screen (figura 12) conferem aos visitantes a autonomia de escolherem acessar todo o conteúdo, na ordem que desejarem ou somente uma fração deste do modo que melhor quiserem. Através dos recursos interativos o visitante torna-se novamente um viajante (agora não somente para Assis, na Itália) do Brasil percorrendo as rotas desbravadas pelos Capuchinhos italianos na Amazônia, seguindo uma linha do tempo-geográfica imagética (figura $13)$.

Figuras 12 e 13: Interatividade tecnológica e projeções audiovisuais

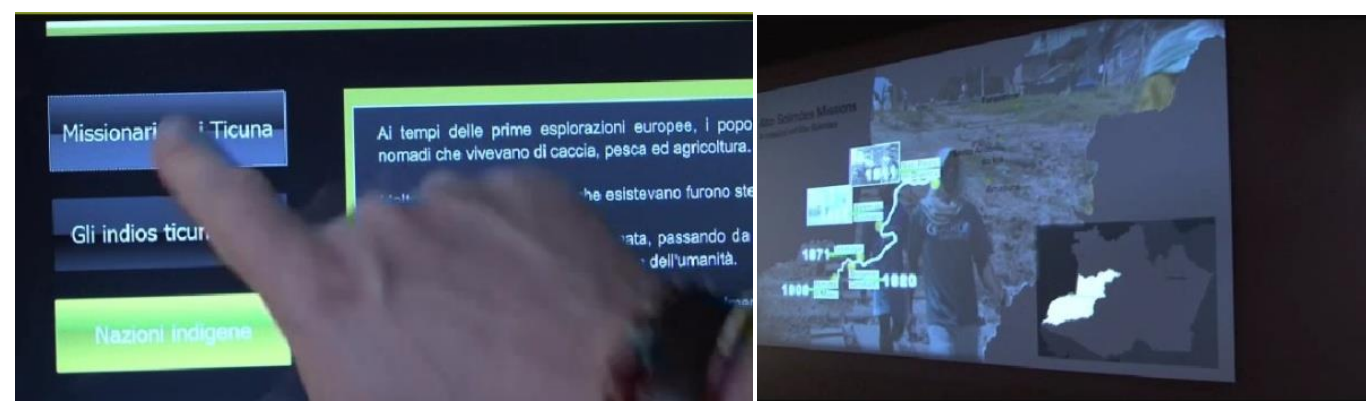

Fonte: http://www.mumamuseo.it, Acesso em: 13/04/2017.

As projeções continuam incentivando a sensação de viagem, onde uma chalana conduz o visitante pelos rios Negro e Solimões, observando as populações ribeirinhas em suas margens, suas casas, seus modos de vida, as crianças brincando, as mães lavando roupas, pescadores cruzando-se com a embarcação, todos fluindo na correnteza das águas (figura 14).

Figuras 14 e 15: Projeção de filme sobre o rio Solimões e nichos térreos com material expositivo
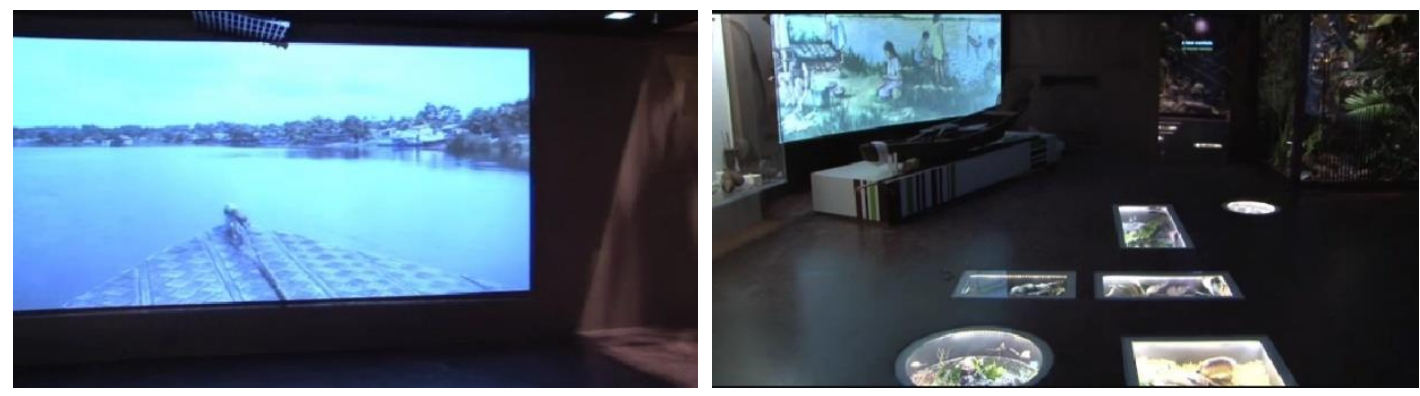

Fonte: http://www.mumamuseo.it, Acesso em: 13/04/2017.

No chão, alguns nichos quadrados e circulares de curta profundidade, iluminados, agregam artefatos e funcionam como expositores térreos protegidos por acrílico (figura 15), uma técnica utilizada também na Igreja de Santa Clara para deixar à mostra as peças encontradas durante as escavações arqueológicas. 
Riccardo Mazza $^{34}$, uma espécie de museum maker ${ }^{35}$ italiano, foi o projetista do MUMA e para ele a instituição se traduz em uma:

[...] filosofia da modernidade com uma cultura tradicional que mesmo em suas complexidades permite um recontar com uma linguagem moderna com informação correta e acessível. O MUMA é um museu que provoca um impacto emocional muito grande, não é apenas um museu arqueológico ou etnográfico. É um museu rico em história contextualizada, em movimento, em experiência com uma linguagem tecnológica criativa.

Uma prova disso é o grande globo (giramundo) cujas projeções compreendem a geografia das missões dos Capuchinhos italianos no Brasil mas em conexão com os demais continentes, criando uma grande teia de significados coletivos entre nações (figura 16).

Figuras 16: Projeções, expositor com ambientação da floresta e giramundo tecnológico

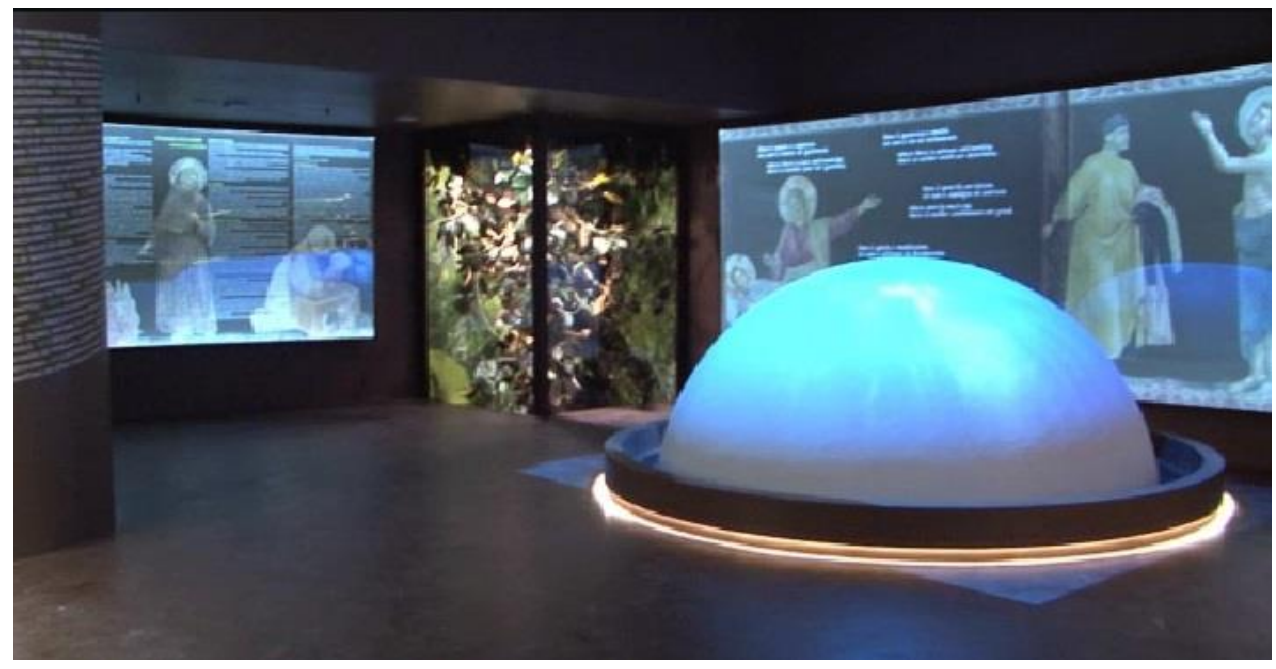

Fonte: http://www.mumamuseo.it, Acesso em: 13/04/2017.

O museu renovado foi inaugurado em 4 de fevereiro de 2011 com as presenças de Domenico Sorrentino, o Bispo de Assis; Carla Casciari, Vice-Presidente da Região da Umbria; Claudio Ricci, prefeito de Assis; Francesco Scoppola, Director Regional de Patrimônio Cultural da Umbria e Frei Antonio Maria Tofanelli, Ministro Provincial dos frades capuchinhos da Úmbria e curador o museu (figura 18).

Figuras 17 e 18: Inauguração do MUMA em fevereiro de 2011

34 Entrevista com o fundador do Estúdio Interativo de Som, um laboratório de pesquisa visual e sonora especializada em design artístico para exposições. Curador e consultor de uso criativo da tecnologia, multimídia e objetos reais em museus, realizada em maio de 2011.

35 "Fazedor de Museus" Tradução livre. Expressão também utilizada para denominar o Planejador de museus tecnológicos brasileiros, Marcello Dantas, responsável pelos projetos do Museu da Língua Portuguesa em São Paulo e do Museu dsa Gente Sergipana em Aracaju.

LCANOA DO TEMPO - O Muma em Assis/Itália e a história dos frades Capuchinhos da Úmbria na 


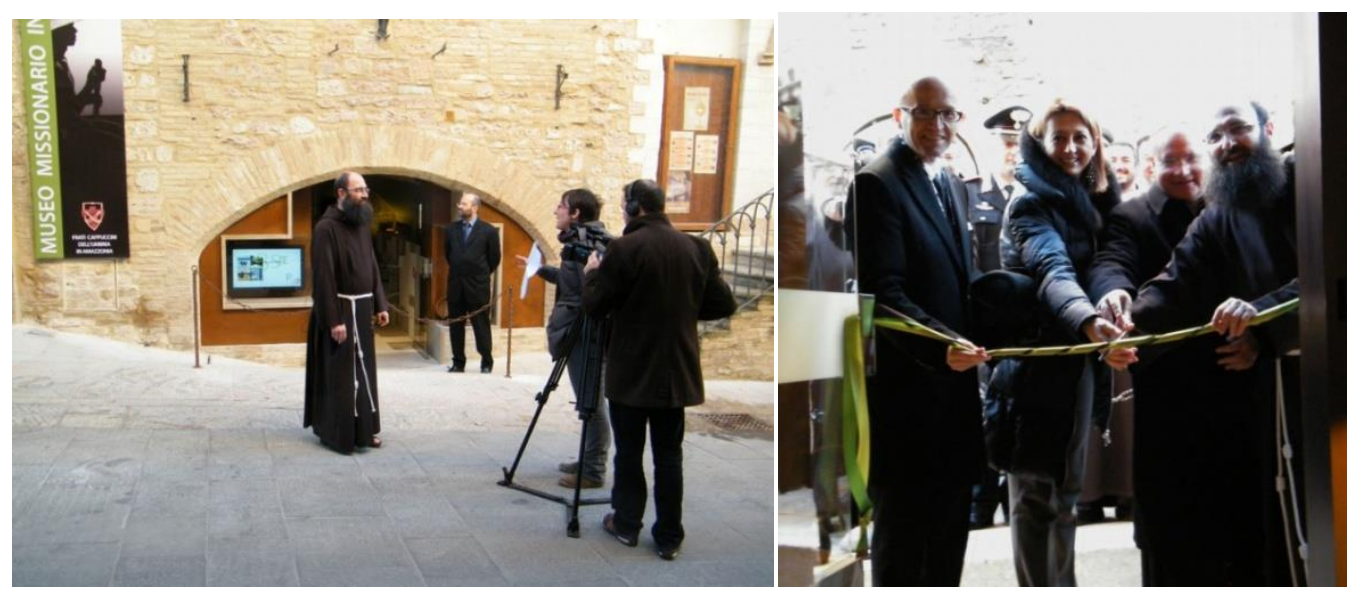

Fonte: http://www.mumamuseo.it, Acesso em: 13/04/2017.

Com o título de único museu multimídia na temática missionária no mundo, o MUMA é motivo de orgulho para seus colaboradores. De acordo com Frei Antonio Maria Tofanelli (figura 17) descreve o MUMA enquanto:

[...] um museu que reconta história dos missionários italianos junto aos índios Ticuna na Amazônia, à uma das maiores florestas do mundo, com uma tecnologia muito avançada, interativa, multimídia, capaz de envolver emocionalmente as pessoas. ${ }^{36}$

A Itália é uma cidade repleta de um culto ao passado corporificado em musealizações, dos museus convencionais "entre quatro paredes" aos museus à céu aberto (com informação pública sobre cada monumento/edifício musealizado e um roteiro museológico que confere autonomia ao visitante) e aos processos de musealização in situ nas ruínas arqueológicas. Assim,

[...] a musealização consiste em um conjunto de processos seletivos de caráter info-comunicacional baseados na agregação de valores a coisas de diferentes naturezas às quais é atribuída a função de documento, e que por esse motivo tornam-se objeto de preservação e divulgação. Tais processos, que têm no museu seu caso privilegiado, exprimem na prática a crença na possibilidade de constituição de uma síntese a partir da seleção, ordenação e classificação de elementos que, reunidos em um sistema coerente, representarão uma realidade necessariamente maior e mais complexa. ${ }^{37}$

O ato de musealizar institui uma "representação social" pois compreende a retirada do uso funcional de um determinado objeto para colocá-lo em relevo como objeto simbólico de uma dado contexto, forma de vida e sociedade produtora. Lida-se com o "espectro do ausente" recriado na narrativa museográfrica. Conforme afirmou o historiador Roger Chartier " [...] a

\footnotetext{
${ }^{36}$ Entrevista com Frei Antonio Maria Tofanelli, Ministro Provincial dos frades capuchinhos da Úmbria e curador do MUMA, realizada em maio de 2011.

${ }^{37}$ LOUREIRO, Maria Lucia de Niemeyer Matheus. Preservação in situ X ex situ: reflexões sobre um falso dilema. 3. ${ }^{\circ}$ Seminário Iberoamericano de Museologia. Madrid, España, 2011. Disponível em: http:// www.siam2011.eu/wp-content/uploads/2011/10/Maria-Lucia-de-Niemeyer-ponencia-Draft.pdf, Acesso em: 08/08/2015, p.2-3.
} 
representação é instrumento de um conhecimento mediato que faz ver um objeto ausente através da sua substituição por uma 'imagem' capaz de o reconstituir em memória e de o figurar tal como ele é". 38

Em Assis, a musealização de sua persona e de sua obra traduzem a representação da ideia de "renúncia", da simplicidade, da escolha pelo voto de caridade, da evangelhização e da vida de absoluta pobreza configuram o "ausente" em meio à riqueza e ostentação de edificações, obras de arte e museus. Fruto de uma escolha, essa representação está diretamente vinculada à construção identitária da própria cidade.

\section{USOS SOCIAIS DE RUÍNAS URBANAS MEDIEVAIS ITALIANAS: A FORTALEZA FRANCISCANA}

As cidades e sua arquitetura, que torna tangível idealizações adaptadas em formas, estruturas, materiais e utilização ao partir de conteúdos simbólicos e referenciais, está aberta à reapropriações, refusões e toda a sorte de transformações que coabitam a existência da vida humana cotidiana que se desenvolve em seus alicerces. Assim, compreende-se a cidade como:

[...] uma obra de arte construída no tempo, artefato moldado pela cultura e pelas necessidades simbólicas dos diversos grupos, concretização de valores e aspirações executada por meio da construção/conformação dos edifícios, dos lugares e da apropriação de elementos da paisagem natural. ${ }^{39}$

Sob esse aspecto, o próprio sentido da ruína enquanto manifestação material sujeita às intempéries atmosféricas que ao longo do tempo tornam-se agentes de deterioração de pedras, rebocos, estruturas, hastes de sustentação, telhamentos, portais e demais características construtivas carrega consigo a historicidade dos usos, dos reusos e mesmo dos desusos.

Várias cidades italianas em seus estilos românicos e góticos, ao longo do século XIX, sofreram intervenções e restauro em estruturas romanas após procedimentos de pesquisa e prospeções arqueológicas. Buscava-se consolidações e reintegração das cultura material edificada da antiguidade com uso de anastiloses. ${ }^{40}$ Havia um respeito quase sacro-sanctum para não se desfigurar os monumentos. ${ }^{41}$

\footnotetext{
${ }^{38}$ CHARTIER, Roger. A História Cultural. Entre práticas e representações. Lisboa: Difel, 2002, p.22.

${ }^{39}$ MENICONI, Rodrigo Otávio De Marco. A construção de uma cidade-monumento: o caso de Ouro Preto. Dissertação de Mestrado em Arquitetura e Urbanismo. Belo Horizonte: Universidade Federal de Minas Gerais, 1999, p. 17.

${ }^{40}$ Anastilose é a recomposição de partes existentes em uma edificação, deixando esses elementos de integração reconhecíveis.

${ }^{41}$ MENICONI, Rodrigo Otávio De Marco. Op. Cit., p.20. 
Contudo, duas concepções da teoria arquitetônica, entraram em colisão à respeito dos procedimentos junto às ruínas: a primeira é a do francês Viollet-le-Duc (1814-1879), profundo conhecedor da arquitetura medieval, para quem as intervenções deveriam "recuperar a unidade de estilo do monumento, reconduzindo-o à sua integridade construtiva e morfológica" utilizando "materiais idênticos aos originais" buscando-se colocar no lugar dos antigos arquitetos e assim pressupondo quais seriam suas ações, efetuando reintegrações mesmo aquelas que jamais tivessem existido, promovendo assim um restauro reconstrutivo e corretor. ${ }^{42}$

A outra vertente, combatente da proposição de Le-Duc, surge na crítica enfática realizada pelo inglês John Ruskin que exige autenticidade, separando e identificando as temporalidades dos materiais construtivos, admitindo apenas a manutenção da ruína como documento de um momento de esplendor, que diluído sob o efeito do tempo e da natureza, deve ser respeitado. ${ }^{43}$

Ao caminhar pelas ruas de Assis deparamo-nos com as pedras calcárias brancas presentes em grande parte das construções, mantidas higienizadas dentro de um processo de conservação preventiva, tendo as demais edificações sido erguidas com pedras vulcânicas de coloração mais avermelhada. A cidade constitui-se como um organismo vivo e ciente de seu valor enquanto patrimônio cultural, mesclando-se aos usos funcionais de seus edifícios.

A Carta de Atenas de 1933, em razão do Congresso Internacional de Arquitetura Moderna - CIAM, propôs sugestões para as cidades com base no cotidiano do "habitar, trabalhar, recrear e circular". Sendo corroborada e aprofundada pela Carta de Veneza, de 1964, na qual se reafirmou a ideia da conservação dos monumentos coligada à "função útil" para a sociedade. $^{44}$

Considerando-se a inserção do MUMA na perspectiva do uso social de ruínas urbanas medievais, deve-se compreender que a edificação da cidade de Assis atendeu aos princípios originários de uma arquitetura italiana autosustentável, principalmente em razão das várias contendas que isolavam seus habitantes do mundo exterior tendo o inimigo em seus portões. A ideia de uma muralha fortaleza para proteção das guerras contrasta com a paisagem de tranquilidade evocada quando se chega à Assis. De acordo com Elsbeth Becker:

[...] construída em pedra, a cidade apresenta-se como uma visão de paz, quando banhada pela clara luz do céu da Úmbria. Na estação do inverno, a visão idílica transforma-se e ganha os contornos da arquitetura envolta no branco da paz, coroada com flocos de neve que se alinham suavemente nas dobradiças e nos telhados seculares. As construções medievais estão por toda

\footnotetext{
42 Idem, ibidem, p.22-23.

${ }^{43}$ Idem, ibidem, p.23-24.

${ }^{44}$ CURY, Isabelle (Org.) Cartas Patrimoniais. Rio de Janeiro: IPHAN, 2000.
} 
parte e resguardam vivos e intactos os lugares do saber medieval e humanístico. Este aspecto é ainda mais valorizado pela harmoniosa relação com uma paisagem doce e meditativa, onde as "pegadas" dos franciscanos conduzem por caminhos antigos, de arquitetura fascinante e de paz espiritual. $^{45}$

Essa descrição apresenta os contornos da identidade da cidade de Assis, das referências que vão se coadunando às suas pedras cruas reluzentes. Lugar de memória, Assis é um espaço definido pela cristandade e sobretudo ao espírito de caridade, de doação e trabalho missionário. Assim, a formação identitária é construída, um produto das relações sociais, históricas e culturais absorvendo a forte religiosidade que propaga a ação evengelizadora.

O espaço de Assis confirma essa construção identitária ao torná-la uma cidade orientada pelo Santuário de São Francisco de Assis, conformada pela Basílica (figura 19) cuja "igreja inferior fala a linguagem mística da contemplação, convida e introduz à oração" tendo o estilo arquitetônico da nave principal, do cruzeiro e da ábside equilibrado pelo gótico das Capelas acrescentadas após $1270 .^{46}$

Figuras 19 e 20: Interior do Santuário de São Francisco de Assis e Cripta com túmulo do Santo.

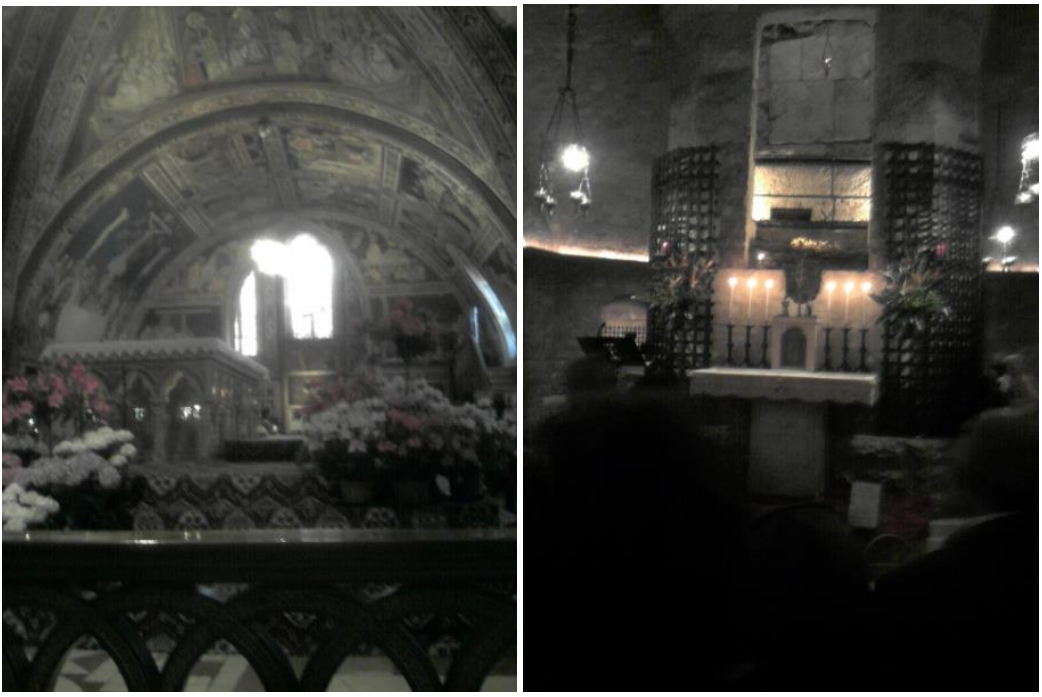

Fonte: Fotografias JCM, 2011.

Perpassando a Capela de Santo Antônio Abade, o Cemitério dos Frades que abriga uma estátua em terracota de São Francisco feita por P. Luigi Sapia (1925), tem-se a Capela de Santa

\footnotetext{
${ }^{45}$ BECKER, Elsbeth Léia Spode. Arte e espiritualidade no Conjunto Basilical de Assis - Itália. Thaumazein, Ano VII, v. 8, n. 15, Santa Maria, p. 109-125, 2015. Disponível em: file:///C:/Users/bom\%20dia/Downloads/613-19403-PB.pdf, Acesso em: 17/04/2017, p.110.

${ }^{46}$ TROIANO, Constantino; POMPEI, Alfonso. Op. cit., p.15.
}

LCANOA DO TEMPO - O Muma em Assis/Itália e a história dos frades Capuchinhos da Úmbria na 
Catarina e abaixo da nave principal a Crípta/Túmulo de São Francisco, num rude sarcófago de pedra no pilar erguido no vão do cruzeiro (figura 20).

A Capela de São Martinho localiza-se à esquerda da nave central apresentando dez quadros contando a vida do Santo, obras de Simone Martini (1320). Ainda há na composição as capelas à direita, de São Ludovico e de Santo Estêvão, a Capela de Santo Antônio no interior da Basílica inferior, a Capela da madalena com decoração de Giotto (1310), a Capela de São Nicolau de Bari, a Capela das Relíquias contendo o hábito, as Regras, as sandálias, uma benção autografada por São Francisco dentre outros objetos de valor sacro e com características de musealização.

No Claustro de Sisto IV foi instalado o Museu Tesouro da Basílica com peças como a Nossa Senhora com o menino, em madeira; a Cruz processional em cobre dourado; o Crucifixo em madeira "Vivus et Triumphans" (século XII), dentre outros objetos que compõem o acervo. Há ainda a Coleção Perkins com 57 peças de autores florentinos, venezianos, veronenses e outros (séculos XIV e XVI), doadas pelo crítico de arte Frederico Mason Perkins, ao Sacro Convento de São Francisco.

Continuando o percurso pela cidade passamos pela Igreja de Santo Estêvão e ao pegar a rua Giotto, quase no fim da subida para a Via Portica, à esquerda estão o Museu e o Foro Romano.

Já o lugar onde nasceu São Francisco Piccolino e que era uma antiga loja de tecido foi convertido em Oratório, depois de 1250. Seguindo à frente chega-se à Catedral de Assis de São Rufino, obra arquitetônica românica de Giovanni de Gubbio (1140). A mesma possui em seu interior um museu com livros, pinturas e ourivezaria.

Na continuidade do percurso estão ainda o Ermo delle Carceri (um espaço beniditino concedido à São Francisco e seus seguidores para recolhimento), a Basílica de Santa Clara, a Igreja de Santa Maria Maior, a Igreja e Abadia de São Pedro do século XII, a Igreja de São Damião, a Basílica de Santa Maria dos Anjos e o Tugúrio de Rivotorto, local de nascimento da Ordem Franciscana.

O MUMA está localizado estratégicamente na parte oeste da cidade, nas proximidades da Basílica de São Francisco, na Via San Francesco, 19d (figura 21). Incorporado à cidade, é um memorial desse espírito que se faz documento/monumento na medida em que registra a história dos Capuchinhos da Úmbria na Amazônia.

Figura 21: Mapa da cidade de Assis com destaque para MUMA e outros patrimônios culturais. 


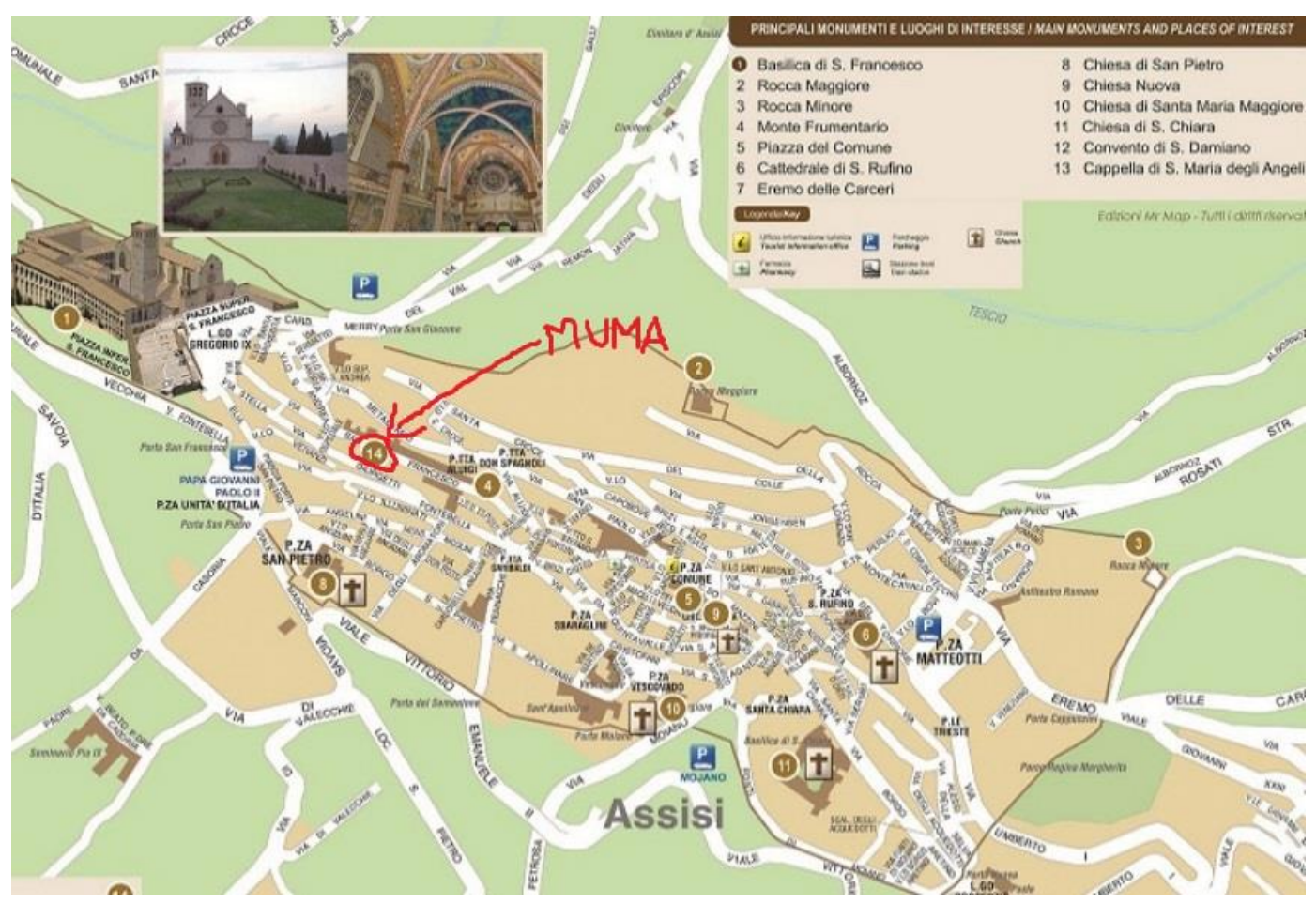

Fonte: http://www.mumamuseo.it, Acesso em: 13/04/2017.

Além da manutenção da memória dos Capuchinhos italianos no Brasil, o MUMA tornase mais um atrativo turístico movimentando a economia local (comércio de alimentos, venda souvenirs, etc.), alimentando direta e indiretamente o processo de geração de emprego e renda dos residentes.

Em uma cidade que "respira musealização da historicidade italiana" por quase todas as partes, o MUMA oferece como diferencial um mergulho em outra cultura - aquela dos índios amazônicos - ensejando um diálogo intercambiante com esse "outro" tão longe e tão perto, tão diferente e tão interessante.

Sua presença na cidade de Assis, ao lado de vários outros patrimônios culturais italianos protegidos pela UNESCO, associa-se ao dever de conservação e salvaguarda da historicidade do espaço urbano. Coexistindo responsabilidades sociais, econômicas, culturais e políticas no âmbito da preservação dos recursos urbanos.

\section{CONSIDERAÇÕES FINAIS}

O Brasil que serviu de abrigo às imigrações italianas dos séculos XIX e XX, através do Museu Missionário Índios da Amazônia encontra o acolhimento para a representação de suas tradições indígenas da floresta no miolo de Assis, na Úmbria. 
Tomando-se a premissa da cultura como ponto fulcral para o entendimento dos fenômenos sociais ocorridos no bojo do contato entre europeus e povos indígenas brasileiros, em um território de lutas pelas riquezas naturais, de exploração do trabalho e pouca presença governamental em obras de primeira necessidade (saúde e educação), o olhar sobre a prática missionária dos frades Capuchinhos italianos e a criação de um museu no coração da Úmbria com testemunhos, acervo e tecnologia multimídia permite interpretar as ações construtivas de representação e identidade.

O museu de Assis reescreve a história com suas próprias tintas, trazendo no touch screen os enlaces de subjetividade necessária ao encantamento dos visitantes de várias partes do mundo que saem da cidade mais devotos e mais tolerantes, mesmo que momentâneamente, pois são estimulados em sua sensibilidade pela iluminação, pelo som ambiente, por toda a tecnologia interativa dos museum makers contemporâneos.

Mais do que um trabalho de caridade nos trópicos, os frades Capuchinhos instituíram um sentido de perpetuação de memórias. Sem negarem o etnocentrismo inicial de sua proposta evangelizadora - enraizada em sua temporalidade -, o MUMA surge como um vetor para consolidar a imagem de uma cultura religiosa dinâmica, que com o passar do tempo vai se transformando, agregando o "diferente" não mais como um "bárbaro inferior", mas como alguém com quem se pode e deve trocar experiências significativas.

As relações da violência simbólica da cristianização sobre as crenças indígenas vistas como "erradas", "pagãs" e "hostis" vão sendo suavizadas através da concepção de sua representação social presente na expografia do MUMA.

Os Ticunas, entre perdas inevitáveis e ganhos possíveis, negociam com os missionários estrangeiros sua fé em troca de uma infraestrutura de escolas e postos de saúde. Do escambo passado com a conquista portuguesa, uma nova troca que possa lhes garantir também a proteção dos patrões dos seringais, dos apropriadores de rios e terras. Para além disso, obtêm ainda visibilidade para suas demandas sociais.

Escapando à ruína de seu próprio povo, estilhaçado pelo domínio colonizador, os Ticunas encontram nas ruínas reluzentes de Assis uma ressignificação de sua trajetória. Se não aparecem como totais protagonistas, por outro lado, deixaram as sombras da invisibilidade para mediarem suas próprias vidas. 